Przegląd Badań Edukacyjnych Educational Studies Review

ISSN 1895-4308

nr 25 (2/2017), s. 229-245

ORYGINALNE ARTYKULY BADAWCZE

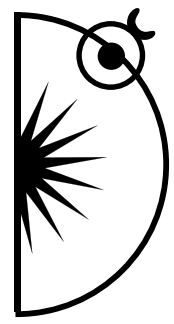

Hanna Solarczyk-Szwec

Uniwersytet Mikołaja Kopernika w Toruniu, e-mail: hanna.solarczyk@umk.pl

Kinga Majchrzak

Uniwersytet Mikołaja Kopernika w Toruniu, e-mail: kingam@umk.pl

Agata Szwech

Uniwersytet Mikołaja Kopernika w Toruniu, e- mail: agataszwech@wp.pl

\title{
Czas jako obszar biograficznego uczenia się w późnej dorosłości w świetle dzienników Haliny Semenowicz*
}

DOI: http://dx.doi.org/10.12775/PBE.2017.028

\section{Time as an Area of the Biographical Learning in Late Adulthood in the Light of the Halina Semenowicz's Diaries}

\begin{abstract}
The article presents the relationship between memory/remembering, Halina Semenowicz's diaries, a biographical learning theory and psychological theories of successful aging. One of the areas of lifelong learning - time - has undergone a detailed analysis from the perspective of the past, present and future in the light of H. Semenowicz's diaries. A frequency analysis (that has been carried out by using the Focusson qualitative data analysis program) gave the ability to generate a conceptual categories which were the scaffolding for the interpretation of the data collected in the H. Semenowicz's diaries. The results of the research allow us to

* W artykule wykorzystano fragmenty prac doktorskich Kingi Majchrzak: „Miejsca jako nośniki pamięci w edukacji studentów Uniwersytetu Mikołaja Kopernika oraz Agaty Szwech: „Biograficzne uczenie się w świetle dzienników H. Semenowicz napisanych pod kierunkiem H. Solarczyk-Szwec i obronionych w 2017r. na Wydziale Nauk Pedagogicznych UMK w Toruniu.
\end{abstract}


draw conclusions that H. Semenowicz's readiness for continuous learning was the result of a combination of positive psychophysical conditions and the philosophy of life, in which life-long learning (understood widely as learning in the course of life, spontaneous, incidental, informal) had an important place. Thus, H. Semenowicz can be an example for others, how to grow old successfully, actively, creatively, in the community with others.

Keywords: Halina Semenowicz, old age, biographical learning, theories of successful aging, subjective sites of memory.

W artykule zaprezentowano czas jako jeden z obszarów uczenia się biograficznego Haliny Semenowicz (1910-2004) - prekursorki pedagogiki Freieneta w Polsce - w świetle jej dzienników z lat: 1979, 1982, 1989, 1992, 1999, 2001. Przeprowadzona za pomocą programu do analizy danych jakościowych Focusson - analiza frekwencyjna - pozwoliła na wygenerowanie kategorii pojęciowych, które stanowiły rusztowanie dla interpretacji danych zgromadzonych w dziennikach Semenowicz. Badania upoważniają do sformułowania wniosku, że gotowość do ciągłego uczenia się Semenowicz była rezultatem pozytywnych psychofizycznych uwarunkowań oraz filozofii życia, w której edukacja przez całe życie - rozumiana szeroko jako uczenie się w toku życia, spontaniczne, incydentalne, nieformalne - zajmowała ważne miejsce. Tym samym autorka dzienników może być przykładem dla innych, jak starzeć się pomyślnie - aktywnie, twórczo i we wspólnocie z innymi.

\section{Rama teoretyczna}

O ile w polskiej literaturze pedagogicznej (w tym andragogicznej) mamy już wiele opracowań dotyczących biografii i sposobów ich badania, w tym serię publikacji pod redakcją Elżbiety Dubas, o tyle mniejszym jak dotąd zainteresowaniem polskich badaczy cieszy się fenomen uczenia się biograficznego. Wprawdzie przy okazji badań biograficznych i uczenia się przez całe życie to zagadnienie najczęściej się pojawia, ale traktowane jest jako oczywistość, rzadko jako zagadnienie pierwszoplanowe, centralne. Jest wiele przyczyn takiego stanu rzeczy. Po pierwsze uczenie się biograficzne pokrywa się znaczeniowo $\mathrm{z}$ innymi rodzajami uczenia się albo je całkowicie wchłaniając, albo stanowiąc ich istotny aspekt. P. Alheit utożsamia uczenie się biograficzne z uczeniem się całożyciowym, faworyzując to pierwsze, w którym widzi szansę na wypełnienie epistemologicznej pustki edukacji całożyciowej. Peter Jarvis zakłada, że 
„[...] proces uczenia się lokuje się w ludzkiej biografii i społeczno-kulturowym środowisku życia, a ich krzyżowanie się prowadzi do wytwarzania się doświadczenia" (cyt. za Malewski, 2010, s. 101), nazywając ten proces uczeniem się egzystencjalnym o znaczeniu jeśli nie tożsamym, to bliskoznacznym z pojęciem i przebiegiem uczenia się biograficznego. Alicja Jurgiel-Aleksander (2013, s. 46-47) wiążę biograficzne uczenie się z uczeniem się z doświadczenia i przez doświadczenie, ale rozumianym szerzej niż w koncepcjach Deweya i Kolba - doświadczenia jako potencjału dorosłego, konstrukcji, która jest społecznie i kulturowo wytwarzana, a jej biograficzność nadaje ton uczeniu się dorosłego w różnych światach życia. Alicja Kargulowa (2012, s. 148-153) widzi przejawy biograficznego uczenia się w różnych teoriach andragogicznych: uczenia się sytuacyjnego, egzystencjalnego, emocjonalnego i przez poszerzanie, formułując wniosek, że „biograficzne uczenie się można określić całożyciowym procesem biograficznej konstrukcji, dekonstrukcji i rekonstrukcji pragnień i «rzeczywistości», a udział poradnictwa w tej (trans)formacji może, w zależności od sposobu realizacji zamierzeń uczących się, być albo znaczny, albo ograniczony" (s. 154). Agnieszka Bron (2006, s. 17) podkreśla, że w uczeniu się biograficznym kluczową rolę odgrywa refleksja i samorefleksja, a narracja (opowiadanie) o własnym życiu jest podstawowym instrumentem tego typu uczenia się. W polskiej powojennej andragogice prekursorką szerokiego ujęcia procesu uczenia, silnie związanego z biografią jest Olga Czerniawska, co zaowocowało ukonstytuowaniem się po 1989 r. nurtu biograficznego w polskich badaniach i praktyce edukacyjnej z licznymi jego reprezentantami. W rezultacie można przyjąć za Jurgiel-Aleksander (2013, s. 55), że biograficzne uczenie się ,[...] to teoretyczna perspektywa we współczesnej andragogice, która zwraca uwagę na to, że dorosły, poruszając się własną ścieżką edukacyjną, dokonując wyborów i kształtując swoją karierę, korzysta z różnych form uczenia się, kształtuje doświadczenia w różnych środowiskach i w różny sposób". Takie szerokie rozumienie uczenia się (biograficznego) jest bliższe życiu, ale w teorii trudne do zoperacjonalizowania oraz skomplikowane w opisie, aby ukazać różne jego aspekty, wymiary, warstwy, związki, napięcia. Niemniej próby takie były już podejmowane. W tym miejscu skupię się na polskich ujęciach tego zagadnienia. Ewa Skibińska (2006, s. 158) wskazała na trzy wymiary uczenia się biograficznego: indywidualny, społeczny i instytucjonalny, które wzajemnie się uzupełniają, krzyżują i nachodzą na siebie. Elżbieta Dubas (2015, s. 27) poświęciła temu zagadnieniu liczne publikacje, z których wyłania się bardzo złożony obraz uczenia się biograficznego, który definiuje jako „,...] specyficzny proces uczenia się, realizowany przez człowieka podejmującego namysł nad swą biogra- 
fią oraz poznającego i zmieniającego siebie oraz swój świat życia w wyniku tej refleksji. Bazuje ono na doświadczeniach życiowych jednostki, ma wymiar emocjonalny, poznawczy i społeczny, a także aksjologiczny i egzystencjalny. Jest celowe i sprzyja modernizacji tożsamości. Ma wymiar praktyczny w tym sensie, że przyczynia się do efektywniejszego funkcjonowania $\mathrm{w}$ zmieniającym się i trudnym świecie. Najczęściej nie bywa uświadomione, lecz można je uświadamiać i wyzwalać. Jest zakotwiczone we wszystkich wymiarach czasu. Silnie opiera się na strukturach społecznych, w tym instytucjach edukacyjnych, które poczynając od nauki szkolnej w dzieciństwie, nadały określone formy i schematy uczeniu się człowieka. Im edukacja bardziej podmiotowo-wyzwalająca, ukierunkowana na samodzielne rozwiązywanie zadań społecznych i zarazem na samorealizację jednostki, tym procesy biograficznego uczenia się są bardziej widoczne". Każda dziedzina życia może być obszarem biograficznego uczenia się, np. komunikowanie, cielesność, czas, przestrzeń, sztuka, obywatel, moralność, technika i zmysł naukowy (Lengrand, 1995).

Uczenie się biograficzne jest splecione nierozłącznie z pamięcią, która jest zmienna, procesualna i wielokrotnie rekonstruowana (Wylęgała, 2014, s. 76). Badacze wskazują na kontekstualność, nielinearność i wielowymiarowość pamięci istniejącej nie tylko jako potencjał zgromadzonych wspomnień, przeżyć, obrazów, wzorów postępowania, itd., ale także jako zasób nieustannie aktualizowany/modyfikowany w zależności od uwarunkowań zakotwiczonych w teraźniejszości (Hirszowicz, Neyman, 2001, s. 26), zasób, który stanowiąc źródło budulca jednostkowych i zbiorowych tożsamości, oddziałuje na procesy decyzyjne, a zatem stanowi o przyszłości.

Interesującej poznawczo koncepcji wyjaśnienia mechanizmów kierujących zmiennością wyobrażeń o przeszłości pod wpływem teraźniejszości dostarczają prace Aleidy Assmann, która wyróżniła dwa wymiary pamięci: wymiar ars oraz wymiar vis. Pierwszy z nich powiązany jest $\mathrm{z}$ naturalną funkcją ludzkiej pamięci umożliwiającą mnemoniczne przyswajanie wiedzy, czyli z procesem magazynowania szeroko rozumianych wspomnień, pojmowanym jako składowanie, niemal archiwizowanie informacji. Wymiarowi temu badaczka przeciwstawiła wymiar vis związany z procesualnością pamięci, czyli pamiętaniem. Wspomnienia są bowiem nie tylko przechowywane, ale także odtwarzane, a każdy akt odtworzenia pociąga za sobą ich transformacje, a nawet przekształcenie czy deformacje. Jest tak dlatego, iż pamiętanie można traktować jako „(...) immanentną siłę, jako rządzącą się własnymi prawami energię. Energia ta może ograniczać możliwość odtworzenia, jak w przypadku zapominania, lub ją blokować, jak w przypadku wyparcia, może też — poddając się działaniu rozsądku, woli 
bądź zmienionego kontekstu zapotrzebowań - doprowadzić do przedefiniowania pamiętanych treści” (Assmann, 2009, s. 117).

Choć przywykliśmy myśleć, że pamięć jest własnością, atrybutem poszczególnych jednostek, to pamięć indywidualna, określana częstokroć mianem autobiograficznej (Maruszewski, 2005, Rubin 1997), stanowi jeden z rodzajów pamięci, który powstaje w komunikacji z innymi osobami (Assmann, 2003, s. 13). Właściwa każdemu człowiekowi pamięć jednostkowa, pojedyncza, niepowtarzalna, kontekstualna i bardzo krucha konstruowana jest dzięki subtelnej analizie indywidualnego doświadczenia przynależności grupowej oraz zdobytej dzięki temu doświadczeniu wiedzy uzyskanej od innych będących depozytariuszami pamięci ponadjednostkowej. Nitek pamięci ponadjednostkowej, pamięci zbiorowej, podobnie jak jednostkowej, może być niezliczenie wiele. W zależności od kontekstu można mówić, m.in. o pamięci członków określonej zbiorowości o jej dziejach, jak i o pamięci danego pokolenia; pamięci ofiar i sprawców; pamięci zwycięzców i przegranych; polskiej pamięci zbiorowej, czy też pamięci zbiorowej ukraińskiej mniejszości etnicznej; pamięci powszechnie uznawanej, instytucjonalnej i transmitowanej przez oficjalne środki przekazu, jak i pamięci funkcjonującej poza tym wiodącym/mainstreamowym obiegiem, zawierającej treści, które niekiedy diametralnie różnią się od treści tej pierwszej (Szacka, 2006, s. 38-39).

Tym co wyróżnia pamięć zbiorową jest natomiast perspektywa długiego trwania (Górny, 2014, s. 92-94), fakt, że zapisanie się w niej może być dla człowieka przepustką do nieśmiertelności. Bez świadomości istnienia pamięci zbiorowej, której depozytariuszami są pojedyncze osoby, znacznie trudniej byłoby znieść człowiekowi myśl o przemijaniu. Kres życia oznaczałby wówczas dla niego koniec istnienia, zapomnienie, nicość, niebyt. Jak twierdzi Zygmunt Bauman (1998, s. 153-154), to właśnie pamięć zbiorowa staje się gwarancją człowieczego non omnis moriar, gdyż pozwala wierzyć, że po naszej śmierci, pamięć o nas, o naszych czynach, przetrwa w świadomości kolejnych pokoleń.

Z kruchości i niedoskonałości ludzkiej pamięci, a równocześnie jej potencjału, zdawali sobie sprawę nasi przodkowie. Dlatego ludzkość - w sposób mniej lub bardziej świadomy - wytwarza nośniki pamięci, które wraz z postępem cywilizacyjnym stawały się coraz liczniejsze i bardziej zróżnicowane. W szerokim ujęciu mianem tym określić można wszystko, co nosi jakiekolwiek znamiona symboliczności (a praktycznie w każdym wytworze kultury takich znamion można się doszukać); wszystko, co jest środkiem komunikacji między ludźmi, a tym samym może być także środkiem komunikacji pomiędzy pokoleniami i epokami (Golka, 2009, s. 71-72); wszystko, co bez względu na formę 
umożliwia realizację celu, jakim jest podtrzymywanie pamięci (ponad)jednostkowej, pozwala na magazynowanie wspomnień, które czasami urastają do rangi legend, a następnie mitów, konsolidujących daną zbiorowość i ułatwiających jednostce odpowiedź na pytania: Skąd przyszedłem? Co jest moim celem? Kim jestem lub kim być powinien (Kula, 2002, s. 7)? Ale tylko niektóre z wytworzonych nośników pamięci uaktywniają się, tzn. są przez jednostki zauważane i wykorzystywane. Posługując się terminologią zaproponowaną przez Pierre'a Nora, naczelne, centralne dla danej społeczności aktywne nośniki pamięci, których odniesienie do przeszłości jest powszechnie odczytywane, i które mają wyrazistszy od innych symboliczny charakter, określić można mianem miejsc pamięci (Nora, 2001). Współcześnie miejscami pamięci określa się wszelkie niemal przejawy obecności przeszłości we współczesności (Kończal, 2007, s. 11). Za metaforyczne miejsce pamięci - ważne nie tylko z punktu widzenia narodu, ale również innych, mniejszych wspólnot, takich jak: rodzina, grupa etniczna, partia polityczna (Nora, 1974, s. 401) - uznaje się nie tylko miejsca geograficzne czy architektoniczne, ale "każdą materialną lub idealną jednostkę znaczącą" (Kończal, 2009, s. 211). Miejscami pamięci mogą być zatem realne i mityczne postaci, wydarzenia, daty, pieśni, hasła, symbole, święta, rytuały, pielgrzymki, instytucje, zdjęcia, dzieła sztuki, teksty literackie, literatura dokumentu osobistego - listy, pamiętniki, dzienniki, itd. Takim miejscem pamięci są dla nas pozostawione przez Halinę Semenowicz (1910-2204) - prekursorkę alternatywy edukacyjnej pod postacią Ruchu Freinetowskiego w Polsce dzienniki, które prowadziła w późnej dorosłości (1968-2004), opisując swoją codzienność, zmaganie się ze zwykły szarym dniem i chorobami oraz komentując rzeczywistość społeczno-polityczną Polski lat 80. i 90. XX w. Upływ czasu spowodował, że jest dziś mniej znana młodszemu pokoleniu pedagogów, dlatego celem podjętych badań jest także przypomnienie tej ważnej dla polskiej pedagogiki postaci.

\section{Metodologia badań}

Przedmiotem poznania w niniejszym artykule, będącym fragmentem szerszego projektu badawczego (Semenowicz et al. 2014; Solarczyk-Szwec, Szwech 2016, Szwech 2017), jest czas jako obszar biograficznego uczenia się w okresie późnej dorosłości Haliny Semenowicz. Przedmiotem badania uczyniono sześć wybranych kalendarzy z lat: 1979, 1982, 1989, 1992, 1999, 2001 roku. Wybór został podyktowany zamiarem ukazania dokonujących się na przestrzeni czasu zmian w obrębie tożsamości autorki dzienników oraz zawartością/ te- 
matyką analizowanych dzienników. Zeszyty z 1979 i 2001 roku to pierwszy i ostatni w całości zapisany dziennik, można je określić jako graniczne, wyznaczające ramy początku i końca prowadzonych zapisów. Dziennik z 1982 roku ukazuje realia życia autorki w czasie stanu wojennego, nastroje panujące w jej najbliższym otoczeniu, opisy strajków robotniczych. Z kolei 1989 rok był dla Polski przełomowym w kwestiach polityczno-gospodarczych. Rozpoczęły się obrady Okrągłego Stołu, odbyły się pierwsze częściowo wolne wybory do Sejmu i Senatu, premier Tadeusz Mazowiecki wraz z nowo powołanym rządem rozpoczął przygotowanie reform gospodarczych w kraju. Rok 1992 wypełniały wydarzenia z życia osobistego diarystki: 21 marca zmarł Jerzy Stajuda - znany malarz, partner starszej córki - Aleksandry Semenowicz. Ważnym wydarzeniem w roku 1992 były wyjątkowe wakacje spędzone na Mauritiusie przez Semenowicz z córkami. Rok 1999 był szczególny w życiu Haliny Semenowicz - 8 czerwca po kilkuletniej chorobie zmarła jej młodsza córka Danuta, która na stałe mieszkała w Paryżu. Zapisy w nim czynione skupiały się najpierw na wiadomościach o stanie zdrowia chorej, a później na przeżywanej żałobie.

W projekcie badawczym szukano odpowiedzi na pytania: Jak przebiegał proces starzenia się Haliny Semenowicz? Czego, kiedy i jak uczyła się w starości Halina Semenowicz? W poszukiwaniu odpowiedzi na te pytania podążano zarówno drogą indukcji, jak i dedukcji, dążąc do zbudowania jednostkowej teorii uczenia się w starości w jakościowym paradygmacie badań.

Analiza i opracowanie materiału badawczego przebiegało w kilku etapach

1. Określenie na podstawie literatury przedmiotu kategorii, które stanowiły podstawowe kierunki odczytania analizowanych dzienników. Były nimi obszary uczenia się pochodzące z pracy „Obszary permanentnej samoedukacji” pod redakcją P. Lengranda, tj. komunikowanie, cielesność, czas, przestrzeń, sztuka, obywatel, moralność, technika oraz zmysł naukowy.

2. Opracowanie zestawu pojęć stanowiących rozwinięcie wyjściowych kategorii z wykorzystaniem analizy frekwencyjnej za pomocą programu do analizy danych jakościowych Focusson. Do analizy wybierano wyrazy bliskoznaczne dla wcześniej wskazanych kategorii.

3. Uporządkowanie zestawu kategorii wyodrębnionych z literatury przedmiotu oraz pojęć wyodrębnionych na podstawie analizy frekwencyjnej pod postacią planu analizy danego obszaru.

4. Przedstawienie uporządkowanych zestawów kategorii i pojęć w postaci opisu analizowanego obszaru uczenia się. 
W świetle wcześniejszych rozważań osoba i dzieło Haliny Semenowicz oraz jej dzienniki stanowią także miejsca pamięci dla bliskich, przyjaciół, studentów, pedagogów - praktyków i teoretyków.

\section{Czas jako obszar uczenia się w dziennikach Haliny Semenowicz}

Wymiar temporalny to jeden z najważniejszych wymiarów ludzkiego doświadczania życia codziennego. Jest on zjawiskiem wielowymiarowym, a nade wszystko subiektywnym. Edward T. Hall (1999, s. 9) zaznacza, że czas to „podstawowy organizator wszystkich aktywności, jako syntezator i integrator, sposób obchodzenia się z priorytetami i kategoryzowania doświadczeń, mechanizm sprzężenia zwrotnego dla tego, co i jak się dzieje, miarką, według której ocenia się kompetencje, wysiłek i osiągnięcia (...). Czas jest systemem głębokim życia kulturalnego, społecznego i osobistego. W zasadzie nic nie odbywa się poza jakąś ramą czasową". Czas to także przestrzeń ludzkiego rozwoju, w której podmiot dokonuje refleksji, kształtuje własną hierarchię wartości, uczy się, a nawet planuje (Pineau, 1995, s. 89). Życie jest zadaniem, które polega, między innymi, na konieczności stałej oceny własnego życia. „Czym bardziej życie się oddala, lata kumulują i więcej jest materii do interpretacji, więcej także potrzeba pracy do jego interpretacji, która w rezultacie pozwala odnaleźć sens życia" (Dubas, 2000, s. 44-45). Okres starości oznacza zatem nową, dalszą edukację realizowaną na bazie potrzeby budowy swej tożsamości na nowo poprzez reinterpretację swojej dotychczasowej biografii.

Dzienniki Haliny Semenowicz charakteryzują się bogatą refleksją temporalną. Dla diarystki czas miał istotne znaczenie, był ważnym obszarem jej życia, o czym świadczy częstotliwość pojęć, jakimi posługiwała się we wpisach wyrażając swój stosunek do czasu. Przedstawia je wykres 1.

Można przypuszczać, że przyczyną, dla której Halina Semenowicz ,pilnowała" upływu czasu, była potrzeba przypisania różnym zdarzeniom odpowiednich miejsc w czasie, a więc także i potrzeba ich uporządkowania względem siebie, określania ich kolejności. Jak podkreśla Olga Czerniawska (2008, s. 72), „refleksja nad bogactwem życia, nad przemijaniem, nad przeszłością, teraźniejszością i przyszłością, miara tych przestrzeni w naszej pamięci, w naszych projektach życiowych, jest niezwykle ważna i konieczna, jeśli chcemy sporządzać pozytywny bilans życia, przeżywać satysfakcję".

Halina Semenowicz pisząc w dziennikach o przeszłości nawiązywała do wydarzeń z dzieciństwa i młodości: przynależności do harcerstwa oraz wydarzeń z okresu drugiej wojny światowej, którą spędziła we Francji. Czas teraź- 
niejszy na podstawie dzienników łączy się ze stosunkiem diarystki do własnego wieku, postrzeganiem swojej starości, czasu nocnego (Pineau, 1995, s. 93; Czerniawska 1999, s. 77-78) oraz czasu instytucjonalnego (s. 77-78) spędzonego w pensjonacie „Złoty Wiek” w Ładach. Pani Halina nawiązując we wpisach do przyszłości odnosiła się do planów związanych z pozostawieniem po sobie spuścizny dla córek oraz najbliższych przyjaciół w postaci testamentu, twórczości pisarskiej czy fundacji. W swoich rozważaniach o przyszłości diarystka uwzględniała także przyszłość transcendentną - śmierć.

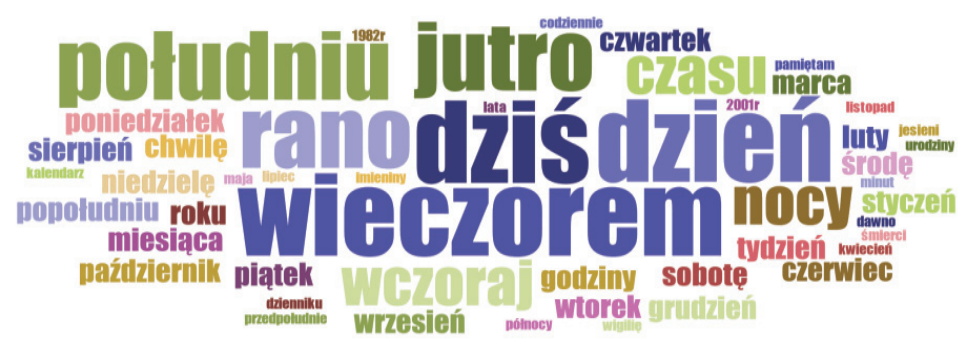

Wykres 1. Frekwencyjność słów w obszarze czas*

Źródło: A. Szwech, Biograficzne uczenie się w świetle dzienników H. Semenowicz, Wydział Nauk Pedagogicznych UMK, Toruń 2017 - niepublikowana praca doktorska.

Przeszłość to „magazyn doświadczeń”, perspektywa, która stanowi o niepowtarzalności człowieka, jego tożsamości. Pogłębiony wgląd w siebie, z perspektywy własnej historii życia, pobudzał Halinę Semenowicz do aktywności intelektualnej i duchowej, do odmiennego postrzegania siebie z perspektywy

* Halina Semenowicz w swoich dziennikach słowa „czas” użyła 605 razy. Nie jest to jednak najczęściej używany przez diarystkę wyraz w odniesieniu do tego obszaru. We wpisach skupiała się głównie na czasie teraźniejszym, na bieżących wydarzeniach, które opisywała. Dlatego najczęściej powtarzające się słowa to „dziš”, które w zapisach pojawiło się 1616 razy oraz „dzień” użyte 1286 razy. Rytm jej codzienności wyznaczany był przez aktywności przypisane do poszczególnych faz dnia. Słowo „rano” występuje w dziennikach 1011 razy, „po poludniu” 658 razy, „południe” - 393 razy, a „przedpołudnie” - 48 razy. W odniesieniu do czasu nocnego słowa „,noc” użyła 479 razy, ,wieczorem”- 1223 razy, „,północ” - 81 razy. Do określania przyszłości i przeszłości diarystka posługuje się słowami ,jutro”, które wymienia 894 razy oraz „wczoraj” 532 razy. Często powtarzającymi się słowami są nazwy dni tygodnia: „niedziela” pojawiło się 319 razy, „,sobota” - 254 razy, ,poniedzialek” - 199 razy, ,piątek” - 182 razy, ,wtorek” - 178 razy, „środa” - 175 razy, ,czwartek” - 171 razy. Pani Halina często używa w zapisach nazw miesięcy: „luty” występuje 166 razy, „,sierpień” - 162 razy, „marzec” - 147 razy, „styczeń” i „wrzesień” 143 razy, ,grudzień” - 140 razy, ,czerwiec” - 137 razy, „październik” - 130 razy, „lipiec” 127 razy, „kwiecień” - 107 razy, natomiast „listopad” - 104 razy, a „maj” - 75 razy. 
czasu, a także twórczej pracy nad sobą. Sięgała do niej także po to, by wykorzystać to, czego się już nauczyła, co było jej pomocne w codziennym życiu. Czytając dzienniki zauważamy, że refleksjadiarystki nad jej przeszłością wywoływała pozytywne skojarzenia $\mathrm{z}$ dobrym zdrowiem, pełnią sił witalnych, planami i aspiracjami z lat młodości, a także nadzieję, że uda się jeszcze osiągnąć nowe cele życiowe.

Świadomość swojego wieku oznaczała w przypadku Haliny Semenowicz akceptację norm przypisywanych starości oraz gotowość podejmowania nowych zadań rozwojowych, dorastania do nich. Czytając dzienniki dostrzegamy, że ich autorka nie odczuwała przygnębienia, czy zdenerwowania z faktu starzenia się oraz przebywania na emeryturze. Organizowała i zapełniała swój czas tak, „aby ze starości nie czynić okresu nudy i bezczynności, lecz okres radości, możliwości ciągłego stawania się" (Chabior, 2000, s. 261). Traktowała czas jako dobro, które należy w pełni wykorzystać. Starała się być ciągle czymś zajęta, zapracowana, nie marnować czasu:

„Rano, po obudzeniu się, czułam, że jestem bardzo samotna i opuszczona. Oleńka zagląda coraz rzadziej i na bardzo krótki czas. Ale zaraz otrząłam się z tego niegodnego starej harcerki nastroju - przypomniałam sobie zdanie z modlitwy Komandora... "zgryźliwi, zgorzkniali starcy, to jedno ze szczytowych osiągnięć szatana". To pomogło. Wstałam, ubrałam się i przystąpiłam do codziennych zajęć" (11.05.1989).

Postrzegając czas jako potencjalną przestrzeń dla rozwoju, Halina Semenowicz uczyła się właściwie organizować czas, by móc żyć w zgodzie z nim, co umożliwiało jej przeżywanie swojego życia właściwie, zgodnie z jej wartościami. Teraźniejszość w dziennikach Semenowicz jawi się więc jako przestrzeń działania, realizacji wyznaczonych celów, urzeczywistniania planów, rozwiązywania problemów oraz zmagania się z towarzyszącymi procesowi starzenia się niedogodnościami fizycznymi. Z zapisów poczynionych w analizowanych dziennikach dowiadujemy się, jak diarystka spędzała czas, co robiła w ciągu dnia. Semenowicz pisała i tłumaczyła na emeryturze książki oraz artykuły dotyczące pedagogiki Freineta, dużo czytała, oglądała filmy i Teatr Telewizji, programy dokumentalne, obrady Sejmu, lubiła też słuchać radia, koncertów muzyki klasycznej. Zwłaszcza w okresie zimowym szydełkowała, haftowała, robiła na drutach swetry, czapki, szaliki dla córek i przyjaciół. Wypełniała czas także rozwiązywaniem krzyżówek, układaniem pasjansów. Halina Semenowicz była bardzo aktywną osobą, często wyjeżdżała do stolicy na spotkania organizowane 
przez animatorów technik freinetowskich, w celu załatwiania spraw urzędowych, na umówioną wizytę u lekarza, w celach towarzyskich, aby odwiedzić przyjaciół lub siostrę. Diarystka w swoim otwockim mieszkaniu przyjmowała wielu gości: przyjaciół, znajome córek, rodzinę, współpracowników polskich i zagranicznych. Była otwarta i gościnna, skupiała wokół siebie osoby w różnym wieku, z różnych środowisk.

Diarystka podkreślała, że nabyła umiejętność samotnego życia (25.02.1982), a pisząc, że dzień upłynął spokojnie i samotnie (07.01.1989) informowała o monotonii dnia codziennego. Refleksja w sytuacji samotności - fizycznego odosobnienia, jak i psychicznego osamotnienia - umożliwiała diarystce bycie z samą sobą, a więc ze swoją pamięcią, co pozwalało jej prowadzić wewnętrzny dialog. Czytając dzienniki odnajdujemy w nich przemyślenia diarystki na temat trosk i mankamentów starości:

„Myślę, że najbardziej uciążliwym atrybutem starości jest niedołęstwo i ciągła zależność od pomocy otoczenia, które mimo najlepszych chęci, ma tyle własnych spraw do załatwienia, że nie może znaleźć czasu dla «staruszków»” (19.10.1989). „Jedna z najtrudniejszych spraw starości to utrata sił oraz sprawności. Trzeba się z tym pogodzić i dostosować swoje plany do możliwości” (25.05.1992).

Diarystka jednak nie postrzegała siebie w kategoriach stereotypowej staruszki: narzekającej i biernej. Nie lubiła przebywać wśród osób starszych - „to zbyt smutne" (12.05.1992). Swoją aktywną postawą starała się zaprzeczaćtemu stereotypowi. Na podstawie przytoczonych wpisów można przypuszczać, że diarystka obawiała się utraty pozycji w najbliższym otoczeniu z powodu mniejszej sprawności fizycznej, ograniczenia umiejętności śledzenia codziennego życia w jego bogactwie, aktywności społecznej i przesunięcia na margines toczącego się życia społecznego, dlatego starała się racjonalizować swoje potrzeby, utrzymywać jak najdłużej dobrą kondycję fizyczną, wyrażającą się w samodyscyplinie; być życzliwą dla świata i ludzi.

Dla człowieka starszego, świadomego przemijania życia, istotnym jest wykorzystanie w pełni teraźniejszości, niemarnowanie czasu „tu i teraz”, przy jednoczesnym zachowaniu umiaru, nie wpadając w chaotyczność działań, w gorączkowy pośpiech i nie wikłając się w nieustanne dylematy wyborów pomiędzy działaniem dziś a odroczeniem działania na jutro. Świadomie przeżywana starość, w której człowiek umie przezwyciężyć skargę i żal przez marzenia i plany, zatrzymuje subiektywne poczucie „bycia bez wieku”, czucia się młodym, uznawania się za nie zmieniającą się w swej ludzkiej egzystencji oso- 
bę, która ma do zrealizowania swoje indywidualne, niepowtarzalne powołanie. Przeżywanie teraźniejszości stanowi podstawę kształtujących się u człowieka starszego nastawień do przyszłości. Dobre funkcjonowanie w teraźniejszości wyposaża jednostkę w umiejętność radzenia sobie z nadchodzącą przyszłością, mimo, że może ona przynieść negatywne doświadczenia związane z procesem starzenia się. Równocześnie świadomość coraz krótszej przyszłości, może prowadzić do intensyfikacji działań podejmowanych przez jednostkę w teraźniejszości.

Człowiek jest istotą prospektywną, w świadomości której znajduje się antycypowanie przyszłości, oczekiwanie na coś. Przyszłość nie jest zatem doświadczana w sposób bezpośredni, lecz jest konstruowanym psychologicznie stanem umysłu, na który składają się lęki, oczekiwania, nadzieje i aspiracje (Włodarczk, 2014, s. 393). Na podstawie dzienników można stwierdzić, że Semenowicz starała się planować swoją przyszłość, co świadczy o dojrzałości diarystki. Postrzeganie przyszłości wymagało od niej budowania w sobie pozytywnego myślenia, racjonalizacji lęków przed tym, co nieznane. Pozytywne nastawienie do przyszłości jest istotnym czynnikiem rozwoju człowieka starego. Na podstawie dzienników można stwierdzić, że Halina Semenowicz była osobą dążącą do zwieńczenia własnego życia poprzez realizację zadań o ważnym znaczeniu. Jej motywacja do działania była wyznaczana przez chęć pozostawienia po sobie wartościowych rezultatów życiowej aktywności, w myśl stanowiska sformułowanego przez E. Eriksona: „Jestem tym, co przetrwa ze mnie". Dlatego Semenowicz spisywała wspomnienia autobiograficzne, myślała o stworzeniu fundacji. Posiadanie celu zachęcało ją do uczenia się gotowości do działania, podejmowania nowych wyzwań, dostarczało jej w okresie starości poczucia zadowolenia i było warunkiem przeświadczenia o sensie życia. Perspektywa przyszłościowa nadawała życiu autorki dzienników nadzieję, optymizm oraz siłę do działania, wiarę we własne zdolności radzenia sobie z nieprzewidywalnymi wyzwaniami na drodze życia. Pozytywne odniesienia do przyszłości były podstawą dobrego samopoczucia diarystki, jej zdrowia psychicznego i fizycznego.

Czytając dzienniki można dostrzec, że ich autorka miała świadomość zbliżającego się końca swojego życia, podejmowała egzystencjalny namysł, refleksję skoncentrowaną wokół życia i śmierci. Jak zaznacza E. Dubas (2012, s. 18) „refleksyjność taka wiąże się z uczeniem się życia i jest swoistą edukacją w nurcie życia, skoncentrowaną wokół fenomenu życia i śmierci. Bez możliwości namysłu i uczenia się nie jest możliwa konstrukcja dojrzałej filozofii życia. Ważnym składnikiem życia jest jego duchowe przesłanie, w którym człowiek 
odzwierciedla swój stosunek do refleksyjnych fenomenów oraz ich aksjologiczną ocenę. Warunkują one mniej lub bardziej dojrzałą postawę wobec życia śmierci - starości. Dojrzałość tej postawy wyraża się w mądrości życiowej, która sprzyja przeżywaniu pomyślnej starości”. Halina Semenowicz nie wspominała jednak w dziennikach wprost o swojej śmierci, nie wybiegała myślami poza czas życia doczesnego. Jako osoba wierząca starała się czynić dobro i nie krzywdzić bliźnich, co miało zagwarantować zbawienie jej duszy i zachować dobrą pamięć o jej istnieniu.

W literaturze zwraca się uwagę na związek pomiędzy trzema wymiarami czasu: przeszłością, teraźniejszością oraz przyszłością w myśleniu indywidualnym,tj. na orientację czasową człowieka. Każda jednostka ma swoją własną perspektywę postrzegania czasu, którą Philip Zimbardo i John Boyd (2009, s. 50) określają jako „osobiste nastawienie, często nieuświadomione, które każdy $\mathrm{z}$ nas przejawia wobec czasu. Jest to również proces, w ramach którego bezustanny bieg życia zostaje podzielony na kategorie czasowe, pomagające nadać naszemu życiu porządek, spójność i znaczenie”. Zdaniem Zimbardo optymalna postawa czasowa dla właściwego i pozytywnego funkcjonowania człowieka składa się z silnej perspektywy przeszłościowo-pozytywnej, umiarkowanie silnej przyszłościowej i umiarkowanie silnej teraźniejszościowo-hedonistycznej, przy równocześnie niskiej perspektywie przeszłościowo-negatywnej i teraźniejszościowo-fatalistycznej (Zimbardo, 2009). Czytając dzienniki Haliny Semenowicz można stwierdzić, że autorkę charakteryzowało poczucie pozytywnej przeszłości, uwzględniała ona perspektywę przyszłościową oraz potrafiła cieszyć się tym, co spotykało ją w teraźniejszości, tym samym była zorientowana pozytywnie wobec perspektyw czasu.

\section{Podsumowanie}

Prowadzone przez 37 lat przez Halinę Semenowicz dzienniki są dzisiaj dla nas ważnym nośnikiem pamięci o tej zasłużonej dla polskiej pedagogiki postaci. Upływ czasu spowodował, że jest dziś mniej już znana młodszemu pokoleniu pedagogów, dlatego podjęcie analiz jej życia traktujemy jako formę przywoływania i wzbogacania pamięci o niej i świecie widzianym z jej perspektywy. W niniejszym artykule został ukazany jeden z obszarów uczenia się Haliny Semenowicz - czas - analizowany w trzech perspektywach: przeszłości, teraźniejszości i przyszłości przez pryzmat teorii całożyciowego i biograficznego uczenia się. W świetle tych teorii nasza bohaterka jawi się jako osoba, która bardzo dobrze zarządza swoim czasem teraźniejszym, ma pozytywny stosunek do 
przeszłości i przyszłości, stawiając sobie ciągle nowe zadania na miarę swoich możliwości. To motywuje ją do ciągłego działania, zbierania i weryfikowania doświadczeń, bycia na bieżąco z wydarzeniami życia społecznego i politycznego, co stanowi o jej optymalnej adaptacji do warunków życia w późnej dorosłości. Halina Semenowicz jawi się też jako aktywny podmiot procesu uczenia się - posiadałaumiejętność rozumienia napotykanych sytuacji, dostrzegając w nich walory edukacyjne. Efektywność jej uczenia przejawiała się zaangażowaniu emocjonalnym oraz podejmowaniu działań. Praktyczne wykorzystywanie nabytej przez diarystkę wiedzy pozwalało w pełni ją zinternalizować oraz rozwinąć cechy niezbędne do samodzielnego życia w ciągle zmieniającym się społeczeństwie. Emancypacyjny wymiar uczenia się w późnej dorosłości wyraża się w pokonywaniu przez Halinę Semenowicz ograniczeń starości, nieuleganiu sytuacjom traumatycznym, szukaniu pozytywnych stron różnych wydarzeń jako źródła energii życiowej, co sprawiło, że do późnych lat swojego długiego życia pozostała osobą niezależną. Bilans jej życia jest pozytywny, ma zintegrowaną osobowość, dlatego Semenowicz w starości była osobą spełnioną i zadowoloną z życia.

Wskazane cele, przebieg i rezultaty uczenia się w starości Semenowicz korespondują z psychologicznymi teoriami pomyślnego starzenia się (Zając-Lamparska, 2012, s. 89-105). Badana nie doświadczyła niepełnosprawności i przewlekłych chorób, była aktywie zaangażowana w życie i zachowała wysoki poziom funkcjonowania poznawczego i fizycznego (Zając-Lamparska, 2012, s. 95). Kontynuowała styl życia, preferencje i zwyczaje, relacje społeczne i schematy myślenia z wcześniejszych lat (Zając-Lamparska, 2012, s. 92). Potrafiła wykorzystywać procesy selekcji, optymalizacji i kompensacji do osiągania satysfakcji z życia, co w świetle modelu SOC P. Baltesa i M. Baltes pozytywnie koreluje z dobrostanem psychicznym, pozytywnymi emocjami, brakiem poczucia osamotnienia, umiejętnością dostosowania się do wymogów środowiska i akceptacją siebie (s. 100). Z biografii Semenowicz wynika, że gotowość do ciągłego uczenia się była rezultatem pozytywnych psychofizycznych uwarunkowań oraz filozofii życia, w której edukacja przez całe jej życie zajmowała ważne miejsce.

\section{Bibliografia}

Assmann A. (2009). Przestrzenie pamięci. Formy i przemiany pamięci kulturowej. W: Saryusz-Wolska M. (red.), Pamięć zbiorowa i kulturowa. Współczesna perspektywa niemiecka, Kraków. 
Assmann J. (2003). Pamięć zbiorowa i tożsamość kulturowa. Borussia. Kultura. Historia. Literatura, nr 29.

Bauman Z. (2013). O pamięci raz jeszcze. http://socjoszpieg.blox.pl/2006/12/O-pamieci-raz-jeszcze.html, (dostęp: 25.02.2013).

Bauman Z. (1998). Śmierć i nieśmiertelność. O wielości strategii życia. Warszawa.

Bron A. (2006). Rozumienie uczenia się w teoriach andragogicznych. Teraźniejszość - Człowiek-Edukacja, $\mathrm{nr} 4$.

Chabior A. (2000). Sytuacja rodzinna seniorów na przykładzie badań prowadzonych w województwie świętokrzyskim. W: Dzięgielewska M. (red.), Przestrzeń życiowa i społeczna ludzi starszych, Łódź.

Dubas E. (2012). Sztuka starzenia się - uczenie się w starości. Kontekst andragogiczny. W: Dubas E., Wąsiński A. (red.). Edukacyjna przestrzeń starości. Wybrane konteksty refleksji i badań, Katowice.

Dubas E. (1998). Biograficzność w oświacie dorosłych - wybrane stanowiska. Edukacja Dorostych, nr 3.

Dubas E., Świtalski W. (red.) (2011). Uczenie się z własnej biografii. T. 1, Łódź.

Dubas E., Świtalski W. (red.) (2012). Uczenie się z biografii innych. T. 3, Łódź.

Dubas E., Stelmaszczyk J. (red.) (2014). Biografie edukacyjne. Wybrane konteksty. Łódź.

Dubas E., Stelmaszczyk J. (red.) (2015). Biografia i uczenie się. T. 4, Łódź.

Golka M. (2009). Pamięć społeczna i jej implanty. Warszawa.

Górny M. (2014). Długie trwanie. W: Saryusz-Wolska M., Traba R. i in. (red.). Modi memorandi. Leksykon kultury pamięci. Warszawa.

Hall E. T. (1999). Taniec życia. Warszawa.

Hirszowicz M., Neyman E. (2001). Społeczne ramy pamięci. Kultura i Społeczeństwo, nr 3-4.

Jurgiel-Aleksander A. (2013). Doświadczenia edukacyjne w perspektywie andragogicznej. Studium biograficzno-fenomenograficzne. Gdańsk.

Kargulowa A. (2012). Poradnictwo w perspektywie biograficznego uczenia się. Rocznik Lubuski, t. 38, cz. 2.

Kończal K. (2009). Bliskie spotkania z historią drugiego stopnia. W: Szpociński A. (red.). Pamięć zbiorowa jako czynnik integracji i źródło konfliktów. Warszawa.

Kończal K. (2007). Polsko-niemieckie miejsca pamięci. Borussia. Kultura. Historia. Literatura, $\mathrm{nr} 41(41)$. 
Kula M. (2002). Nośniki pamięci historycznej. Warszawa.

Lengrand P. (1995). Obszary permanentnej samoedukacji. Warszawa.

Majchrzak K. (2017). Miejsca jako nośniki pamięci w edukacji studentów Uniwersytetu Mikołaja Kopernika. Toruń, Wydział Nauk Pedagogicznych UMK - niepublikowana praca doktorska.

Malewski M. (2010). Od nauczania do uczenia się. O paradygmatycznej zminaie $w$ andragogice. Wrocław.

Maruszewski T. (2005). Pamięć autobiograficzna. Gdańsk.

Nora P., (2001). Czas pamięci, Res Publica Nowa, nr 7.

Nora P. (1974). Mémoire collective. W: J. Le Goff (red.). Faire d'historie. Paryż.

Pineau G. (1995). Czas i edukacja permanentna. W: Lengrand P.Obszary permanentnej samoedukacji. Warszawa.

Rubin D. C. (red.) (1997). Remembering our past. Studies in autobiographical memory. Cambridge.

Semenowicz H. Dzienniki 1968-2004 (rękopis).

Semenowicz A., Solarczyk H., Szwech A. (red.) (2014). Inspiracje pedagogia freinetowska. Studia, źródła, wspomnienia dedykowane Halinie Semenowicz. T. 1, Torun.

Skibińska E. (2006). Mikroświaty kobiet. Relacje autobiograficzne. Warszawa-Radom.

Solarczyk-Szwec H. (2015). Cztery ćwiartki biograficznego uczenia się. Rocznik Andragogiczny 2015, s. 119-134.

Solarczyk-Szwec H., Szwech A. (red.) (2016). Inspiracje pedagogia freinetowska. Dzienniki Haliny Semenoiwcz - matki i obywatelki. T. 2, Torun.

Szacka B. (2006). Czas przeszły, pamięć, mit. Warszawa.

Szwech A. (2017). Biograficzne uczenie się w świetle dzienników H. Semenowicz. Torun: Wydział Nauk Pedagogicznych UMK - niepublikowana praca doktorska.

Włodarczyk E. (2014). Czas jako wymiar i obszar ludzkich działań (perspektywa pedagogiczna). W: Danilewicz W., Theiss W. (red.). Pedagogika społeczna wobec zagrożeń człowieka i idei sprawiedliwości społecznej. Warszawa.

Wylęgała A. (2014). Przesiedlenia a pamięć. Studium (nie)pamięci społecznej na przykładzie ukraińskiej Galicji i polskich „ziem odzyskanych”. Torun. 
Hanna Solarczyk, Kinga Majchrzak, Agata Szwech Czas jako obszar...

Zając - Lamparska L. (2012). Psychologiczne koncepcje pomyślnego starzenia się człowieka. Rocznik Andragogiczny 2012.

Zimbardo P., Boyd J. (2009). Paradoks czasu. Warszawa.

Zimbardo P., (2009). Wieczna chwila i inne czasy, Charaktery, nr 5, http://charaktery.eu/ artykul/1873 [dostęp: 01.06.2017]. 
